\title{
Impact of Asset Management Companies' Exercise of Voting Rights on Corporate Value
}

\author{
Junesuh Yi, ${ }^{* *}$ Professor, Dongguk University
}

\begin{abstract}
$\langle$ Abstract $\rangle$
This study examines the effects of asset management companies' exercise of voting rights on corporate value. An analysis of 50,198 asset management company votes and 388,486 individual fund votes from 2013 to 2017 reveals that the company rejection rate of firm proposals in shareholder general meetings has more than doubled, from $1.47 \%$ in 2013 to $3.29 \%$ in 2017. The rejection rates of agendas such as dividend payout, M\&A, and appointment of executives are relatively high, whereas the rejection rates of financial statement approval and executive compensation are low. An analysis of the market reaction to asset management companies' exercise of rejection voting rights indicates that the firm's stock price shows excess return on the day of the general meeting and that it continues to rise for the following five days. The rate of cumulative abnormal returns was also statistically significantly positive, especially in 2017. In terms of agendas, there is a positive market reaction to M\&A and appointment of executives but a negative reaction to dividend payouts. This paper also finds that foreign or non-chaebol-affiliated asset management companies further exercise the opposite voting right on proposals, resulting in more positive market reactions.
\end{abstract}

Keywords: Voting Rights; Asset Management Company; Firm Value; Market Response; Stewardship Code

JEL Classification: G23, G32

* This work was supported by the Ministry of Education of the Republic of Korea and the National Research Foundation of Korea (NRF-2017S1A5A2A01026546).

** Corresponding Author. Address: Dongguk Business School, Dongguk University, 1Gil 30, Pilding-ro, Jung-gu, Seoul, Korea 04682; E-mail: jsyieee@gmail.com; Tel: +82-2-2260-8589; Fax: +82-2-2260-3684.

Received: July 30, 2019; Accepted: September 17, 2019 


\section{집합투자업자의 의결권 행사가 기업 가치에 미치는 영향}

이 준 서 (동국대학교 교수)**

본 연구는 집합투자업자의 의결권 행사가 기업가치에 미치는 영향에 대한 분석을 실시했다. 2013년부터 2017 년까지 50,198 건의 집합투자업자 의결권과 388,486 건의 개별펀드 의결권에 대한 분석결과 ' 13 년 $1.47 \%$ 에 불과했던 반대의결권 비율은 ' 17 년 $3.29 \%$ 를 기록, 2 배 이상 증가했다. 안건별로는 이익배당이나 합병, 임원임면 등에 대한 반대비율이 상대적으로 높은 반면 재무제표승인이나 임원보수결정에 대한 반대비율은 낮았다. 집합투자업자가 행사한 반대 의결권에 대한 시장반응 분석결과, 반대의결권이 행사된 기업의 주가는 주총당일 양의 초과수익률을 기록하고 주총일기준 5 일까지의 누적초과수익률도 통계적으로 유의한 양의 계수를 나타냈다. 안건별로는 합병이나 임원의 임면에 대해서는 긍정적인 시장 반응을 보였으나 이익배당에 대해서는 부정적인 시장 반응을 보였다. 동일안건에 대해 반대 펀드 수나 의결권 수에 따른 시장 반응은 펀드 수나 의결권 수가 아주 적거나 많은 경우 양의 초과수익률을 보이는 $U$ 자 형태를 시현했다. 또한 임시주총보다 정기주총 시 반대 의결권을 행사하는 경우 시장 반응은 훨씬 긍정적인 것으로 나타났다. 의결권 행사를 집합투자업자별로 구분하여 분석한 결과 비대기업집단, 외국계 자산운용사들이 반대 의결권을 보다 활발히 개진하는 것으로 밝혀졌다. 또한 반대 의결권 행사가 많은 집합투자업자에 대한 시장반응이 보다 긍정적이었다.

핵심 단어 : 집합투자업자, 의결권, 기업지배구조, 기업가치, 스튜어드십코드

JEL 분류기호: G23, G32

* 본 논문은 2017년 대한민국 교육부와 한국연구재단의 지원을 받아 수행된 연구임(NRF-2017S1A5A2A 01026546).

** 연락담당 저자. 주소: 서울특별시 중구 필동로 1 길 30 동국대학교 서울캠퍼스 경영학과 04682; E-mail: jsyieee@gmail.com; Tel: 02-2260-8589; Fax: 02-2260-3684. 


\section{1. 서론}

간접투자시장 규모가 확대되면서 연기금이나 집합투자업자1)의 역할이 증대되고 있다. 이들이 기업의 주요 의사결정 사안에 대해 주주로 의결권을 행사할 수 있기 때문이다. 기본적으로 기관투자자들의 의사결정 원칙은 선관주의 의무(fiduciary duty) 준수에 있다. 즉 연기금이나 펀드는 수익자 또는 투자자 관점에서 최대의 이익을 추구하는 방향으로 의사결정을 해야 하는 것이다. 주주 본연의 권리 행사를 통해 기업성과를 개선시키고 수익추구를 도모하라는 의미로 해석할 수 있다.

더구나 지난해 7월 말 국민연금이 스튜어드십 코드를 채택함에 따라 기관투자가들의 투자 기업에 대한 경영참여는 본격화될 전망이다. 스튜어드십 코드란 연기금과 집합투자업자 등 주요 기관투자가들이 기업의 의사결정에 적극 참여하도록 유도하는 기관투자가들의 의결권 행사지침이다. 이는 투자자의 이익 극대화를 목적으로 하는 연성규범이다. 스튜어드십 코드는 이미 2016년 말 도입되었으나 그동안 이를 채택한 기관투자자들은 극소수에 불과해 코드의 실질적 수행 실적은 미미한 수준이었다. 하지만 국민연금이 코드를 채택함에 따라 국민연금의 위탁운용 역할을 하는 집합투자업자와 국민연금의 투자전략을 뒤따르는 다른 연기금이나 보험사들도 서둘러 코드를 채택하고 있다.

실제로 한국기업지배구조원에 따르면 2019년 6월 말 기준 스튜어드십 코드를 도입한 기관 투자가는 총 102개이다.2) 이는 2017년 말의 18개, 2018년 말의 76개에 비해 큰 폭으로 증가한 숫자이다. 업권별로는 집합투자업자가 36 개로 가장 많았고, $\mathrm{PEF}$ 운용사가 32 개로 뒤를 이었다. 이밖에 보험사 4 개, 증권사 3 개, 은행 2 개 사 등이 스튜어드십 코드를 도입했다. 또한 참여예정 기관도 31 개에 달하고 있다. 이에 따라 기업들은 경영의 투명성을 제고하고 사회적 책임을 수행하며 지배구조를 개선하는 등 변화된 주주권 행사 환경에 적응해 나가는 전략을 마련해야 할 시점이다.

사실 그동안 미국 등 주요국가 들의 기관투자가들도 의결권행사에 소극적인 입장을 견지해왔다. 선관주의 의무의 방법론상의 모호성과 평가의 사후성, 그리고 금융자본의 경제력 집중 폐해에 대한 비난 등을 피하기 어려웠기 때문이다. 하지만 1990년대 이후 주식시장에서 기관투자가의 비중이 증대되면서 선관주의 의무를 전제로 펀드의 의결권 행사가 확산되었다. 미국의 경우 연기금과 뮤추얼펀드가 의결권 행사에 적극적으로 참여하기 시작하였고 특히 2003년 미국 $\mathrm{SEC}$ 가 모든 뮤추얼 펀드에 대해 의결권 행사 및 이와 관련된 내용의 공시를 의무화함에 따라 기관투자가의 의결권 행사는 피할 수 없는 시대적 조류가 되었다. 기관투자가의 의결권 행사를 원활하게 하기 위한 의결권자문기관의 자문서비스 시장도 확대되고 있다. 기관투자가는 투자대상기업간의 지배구조 및 이해상충 문제를 완화하기 위해 의결권행사 시 외부 의결권 행사 전문기관으로부터 자문을 받기도 한다. 현재 글로벌 의결권 자문기구로는 ISS(Institutional Shareholders Ser-

1) 자산운용사를 의미하는 것으로 자본시장법상의 용어를 준용하여 집합투자업자라고 칭한다.

2) http://sc.cgs.or.kr/participation/investors.jsp. 
Impact of Asset Management Companies' Exercise of Voting Rights on Corporate Value

vice)나 Glass Lewis, Egan-Jones 등이, 국내에는 한국기업지배구조원, 서스틴베스트, 대신지배 구조연구원 등이 있으며 이들이 주요 기업의 주총 안건에 대해 의결권을 자문하고 있다.

한국의 경우도 과거에는 주총의 안건에 대해 다른 주주들의 투표비율에 따라 기관투자자의 의결권을 적용하는 중립투표제(shadow voting)를 시행해왔으나 1998년 증권투자신탁업법의 개정을 통해 펀드가 독립적으로 의결권을 행사할 수 있게 하였다. 이후 2009년 제정된 자본시장법 에서는 펀드의 의결권 행사여부와 구체적인 내용, 행사하지 않는 경우 구체적인 사유를 공시하도록 하고 있으며, 의결권 행사 가이드라인을 내부지침으로 정하여 공시하도록 하고 있다.3) 또한 금융투자협회에서는 '집합투자업자의 의결권행사 가이드라인'이라는 모범규준을 통해 지배구조, 자본구조, 기업의 사회적 책임과 관련된 세부항목에 대해 의결권 행사의 기준을 제시하고 있다.

하지만 국내 기관투자가들의 의결권 행사는 선진국에 비해 체계적으로 수행되지 못하고 있는 실정이다. 특히 연기금에 비해 집합투자업자의 의결권은 훨씬 비체계적으로 행사되는 것으로 알려져 있다. 연기금의 경우에는 기금 규모도 크고 이해관계자들에 의한 모니터링이나 견제세력이 존재하여 의결권 행사가 비교적 투명하게 이루어지고 있다.4) 반면 집합투자업자는 펀드투자자 들의 익명성으로 인해 그렇지 못하다. 실제로 Kim and Yon(2014)은 2005년부터 2011년까지 기관투자가의 의결권 행사 내역을 분석한 결과 국민연금은 평균 $7.46 \%$ 의 반대율을 보인반면 집합투자업자는 이보다 훨씬 낮은 $0.85 \%$ 에 그쳤다.

이 같이 집합투자업자들이 보유 주식에 대해 의결권을 제대로 행사하지 못하는 이유는 집합투자업자 스스로의 지배구조에도 원인이 있다. 금산분리로 산업자본이 은행 지분을 보유 하기는 어렵지만 은행을 제외한 금융기관에 대한 보유는 비교적 자유로워5) 2018년 8월 기준 60 개 대기업집단 중 31 개 집단이 186 개의 금융기관을 보유하고 있다.6) 이 같은 상황에서 대기업 집단 계열의 집합투자업자가 관련 계열사에 대한 의결권 행사 시 독립성 침해 가능성은 상당히 높다고 할 수 있다. 또한 집합투자업자가 투자기업과의 사업상 관계로 인해 발생하는 이해상충 문제도 의결권 행사의 장애요소로 작용한다. 예컨대 집합투자업자가 속해있는 계열사 중에 은행이나 보험, 증권사가 투자기업의 퇴직연금 사업자인 경우 집합투자업자는 의결권을 자유롭게 행사하기 어려울 것이다. 이와 함께 적절한 주주권 행사를 위한 집합투자업자의 열악한 내부조직도 올바른 의결권 행사의 방해요소이다. 대규모 연기금들은 그나마 의결권 행사전문 위원회 등을 운영하고 있으나 집합투자업자의 경우 의결권행사 전담조직이 거의 없고 심지어 의결권 행사와 관련한 적절한 규정조차 마련되어 있지 않은 실정이다.

3) 자본시장법 제 79 조 제 1 항에서는 집합투자업자가 투자자에 대해 선량한 관리자의 주의로써 자산을 운용하여야 한다고 규정하고 있으며 제 87 조 제 1 항 제 9 항까지 집합투자업자의 의결권 행사와 관련해 자세한 내용을 적시하고 있다.

4) 물론 연기금의 경우에도 주주권의 올바른 행사에 대한 의문이 제기되고 한다. 국민연금의 제일모직과 삼성물산 합병 찬성 건이 대표적인 예이다.

5) 공정거래법 상 자산총액 5 조 원 이상의 대기업집단에 속하는 경우 다른 업종의 계열사와 마찬가지로 상호출자제한 규정만이 존재한다.

6) 공정거래위원회 '2018년 대기업집단 주식소유현황 발표’ 2018년 8월 27일자 보도자료. 
한국증권학회지 제48권 6호 (2019)

이에 따라 본 연구에서는 집합투자업자들이 주식을 보유한 기업에 대한 의결권 행사 시 진정으로 선관주의 의무를 다하고 있는가를 종합적이고 체계적으로 분석하고자 한다. 이를 위해 우선 지난 5 년간 집합투자업자가 행사한 총 50,198건의 의결권에 대한 기술통계 분석을 실시한다. 연도별, 안건별로 찬성, 반대, 중립, 불행사 등 의결권이 어떻게 행사되었는가를 살펴보고 그 원인을 추론해 본다. 또한 388,486 건의 개별펀드별로도 연도별, 안건별 의결권 행사 내역을 살펴본다.

본 연구에서는 특히 집합투자업자가 반대 의결권을 행사한 기업에 대해 상세한 분석을 실시한다. 반대 의결권을 행사하는 비율이 지극히 낮은 현실을 감안할 때 집합투자업자가 반대 의결권을 행사한다면 이는 선관주의 의무에 충실했다고 볼 수 있기 때문이다. 즉 집합투자업자가 주식 보유 기업에 대해 경영감시(monitoring) 역할을 제대로 수행했다고 평가할 수 있는 것이다. 이 같은 경우 의결권 행사 기업의 주가 변화를 통해 투자자의 수익증대로 이어질 수 있는가를 검증한다. 의결권 반대 행사 기업의 주가 변화는 연도별, 안건별로 이루어지며 집합투자업자가 보유하고 있는 펀드 숫자별, 그리고 의결권 수별로도 분석이 이루어진다. 동일 집합투자업자가 반대와 찬성을 동시에 행사하는 경우의 기업의 가치변화도 분석하며 이 경우 반대비율에 따른 기업의 가치변화도 측정한다.

이와 함께, 집합투자업자에 대한 분석을 실시, 집합투자업자별로 반대 의결권 행사에 대한 시장반응을 조사한다. 또한 집합투자업자를 대기업집단과 비대기업집단으로 구분하여 이들이 행사한 반대 의결권에 대한 기업가치 변화의 차이여부도 검증한다. 이들 분석은 집합투자업자가 행사했다고 공시한 개별의결권별로 이루어진다. 동일기업의 특정안건에 대해 행사된 의결권을 기준으로 분석을 실시하고 동일기업 특정안건에 대해 의결권을 행사한 집합투자업자 기준으로도 분석이 이루어진다.

본 연구의 구성은 다음과 같다. 제 2 장에서는 선행연구에 대해 살펴보고 제 3 장에서는 자료 및 방법론에 대해 기술한다. 제 4장에서는 여러 가지 실증분석에 대한 결과를 기술하며 제 5장에서는 요약 및 정책적 시사점을 제시한다.

\section{2. 선행연구}

미국에서는 기관투자가의 의결권 행사에 대한 연구가 비교적 활발히 진행되어 왔다. 기관 투자자들의 주주행동이 보유 기업의 주가에 미치는 영향을 중심으로 분석이 이루어졌다. Brickely et al.(1998)은 주주제안이 주주의 이익에 반할 때 대주주들이 반대 의결권을 더욱 강하게 행사한다고 주장했다. Nesbitt(1994)은 미국의 가장 큰 기관투자가 중 하나인 캘퍼스(CalPERS)가 적극적으로 의결권을 행사한 기업의 주가가 큰 폭으로 상승하는 점을 밝혀냈다. 또한 Opler and Sokobin(2000)은 미국 기관투자자협회(CII)가 타깃으로 설정한 기업의 주가가 1년 동안 $10 \%$ 이상 상승했다고 주장했다. 반면 Caton et al.(2001)은 이들 기업의 주가가 하락하는 반대의 연구결과를 발표하기도 했다. 
Impact of Asset Management Companies' Exercise of Voting Rights on Corporate Value

SEC가 뮤추얼펀드의 의결권 행사 공시를 의무화한 2003년 이후에는 기관투자가가 투자자의 이익을 대변하여 선관주의 의무를 충실히 수행하는가에 대한 연구가 주로 수행되었다. 이 중 최근 관심이 집중되고 있는 분야는 사업연관성(business tie)과 관련된 것으로 기관투자자가 사업연관성이 있는 기업들에 대해 의결권을 제대로 행사하는가를 분석하고 있다. Davis and $\operatorname{Kim}(2007)$ 과 Ashraf et al.(2012)은 펀드패밀리 수준에서 사업관련성이 보유 기업의 의결권 행사에 영향을 미치지 않는다고 밝혔다. 반면 Cvijanovic et al.(2016)은 의결권 자문기관인 ISS의 추천의견과 집합투자업자의 규모 통제 후 개별펀드 수준에서 사업관련성이 보유기업의 의결권 행사에 영향을 미치는 것으로 밝혀냈다. 경영자 요청안건과 주주 요청안건을 구분하여 기관투자자의 의결권 행사패턴을 분석하는 연구도 진행 중이다. Ng et al.(2009)은 보유 기업들의 과거 성과에 따라 기관투자자의 의결권 행사 패턴이 변화, 과거 성과가 나쁜 경우에는 주주의 요청안건에 비해 경영자의 요청안건에 대한 반대비율이 높다는 사실을 알아냈다. Rothberg and Lilien(2006)은 대형 펀드패밀리의 경우 경영자의 요청안건에 대해 호의적이라는 연구결과를, Matvos and Ostovsky(2010)는 이사선임과 관련해서 기업 특징에 관계없이 기관투자자들의 일관된 의결권 패턴을 밝혀냈다. Morgan et al.(2011)은 펀드패밀리와 개별펀드 간의 의결권 행사의 상이성에 대한 분석을 실시, 펀드패밀리 내에서 개별펀드들이 통계적으로 유의하게 상이한 의사결정을 내린다는 사실을 밝혀냈다.

한편 기관투자가의 의결권 행사와 관련된 국내 연구는 Suh(2009), Kwon(2016)등 대부분 법이나 제도 개선과 관련된 것으로 실증분석 연구는 지극히 미미하다. 또한 실증연구도 Park et al.(2012)과 같이 국민연금과 관련된 것이 대부분으로 집합투자업자의 의결권과 관련된 연구는 국민연금과 집합투자업자의 의결권 반대 표시에 대한 주식시장의 반응을 분석한 Kim and Yon(2014)이 유일하다. 스튜어드십 코드와 관련된 연구는 Kim and $\operatorname{Im(2018)ㅇㅣ~ㄱㅜㄱㅁㅣㄴㅇㅕㄴㄱㅡㅁㅇㅢ~}$ 스튜어드십 코드 도입을 계기로 2018년 7월 말 기준 국민연금이 5\% 이상 지분을 보유한 기업의 주가에 대한 분석을 실시, 기업지배구조 수준이 상대적으로 낮은 기업의 경우 통계적으로 유의한 초과수익률을 기록해 스튜어드십 코드 도입이 기업가치 향상에 도움을 준다고 주장했다.

\section{3. 자료 및 방법론}

\section{1 자료}

집합투자업자의 의결권 자료는 금융투자협회 공시자료를 통해 확보했다. 금융투자협회 전자공시서비스는 2012 년 6 월 이후의 운용사 펀드의결권과 펀드별 의결권 행사내용을 공시하고 있다. 표본기간은 2013년부터 2017년으로 설정하였다.7)

공시자료에는 운용사와 펀드명 그리고 의결권 행사 기업명이 나타나 있고 의안유형과 보유 주식수, 찬성주식수, 반대주식수, 불행사주식수, 중립행사 주식수 등이 기재되어 있다. 의안유형은 분할(분할합병), 이익배당, 임원보수결정, 임원의 임면, 재무제표승인, 정관변경, 주식매수선택권,

7) 2015년 자본시장법 개정으로 기관투자자의 의결권 행사 내역 공시 시점이 연 1 회 일괄공시로 변경됨에 따라 2017년의 경우 9월 말까지의 자료만을 대상으로 한다. 
한국증권학회지 제48권 6호 (2019)

흡수합병, 기타 등 총 16 개로 구분되어 있다. 주주총회일은 시스템에서 제공하지 않아 별도의 수작업 절차를 걸쳐 자료를 확보하였다.

$<$ 표 $1>$ 은 표본기간 내에 집합투자업자가 행사한 의결권 내용이다. 집합투자업자가 공시한 기업별 안건별 의결권은 총 50,198 건이었으며 이 중 찬성이 45,267 건, 반대 1,403 건, 중립 840 건, 불행사 2,688 건이었다. 8 ) 즉 전체 의결권 중 찬성 $90.18 \%$, 반대 $2.79 \%$, 중립 $1.67 \%$, 불행사 $5.35 \%$ 를 기록했다. 하지만 최근 들어 찬성비율은 감소하는 반면 반대비율은 급증하는 것으로

〈표 1〉집합투자업자 및 개별펀드의 연도별 의결권 행사 현황

(괄호 안은 \%)

\begin{tabular}{|c|c|c|c|c|c|}
\hline & 총안건수 & 찬성 & 반대 & 중립 & 불행사 \\
\hline \multicolumn{6}{|c|}{$\mathrm{A}$ : 집합투자업자 } \\
\hline \multirow[t]{2}{*}{2013} & 7,734 & 7,394 & 114 & 192 & 34 \\
\hline & & $(95.60)$ & $(1.47)$ & $(2.48)$ & $(0.44)$ \\
\hline \multirow[t]{2}{*}{2014} & 10,195 & 9,204 & 274 & 198 & 519 \\
\hline & & $(90.28)$ & $(2.69)$ & (1.94) & (5.09) \\
\hline \multirow[t]{2}{*}{2015} & 10,773 & 9,516 & 304 & 155 & 798 \\
\hline & & (88.33) & $(2.82)$ & (1.44) & $(7.41)$ \\
\hline \multirow[t]{2}{*}{2016} & 12,841 & 11,377 & 426 & 215 & 823 \\
\hline & & $(88.60)$ & $(3.32)$ & $(1.67)$ & $(6.41)$ \\
\hline \multirow[t]{2}{*}{$2017^{*}$} & 8,655 & 7,776 & 285 & 80 & 514 \\
\hline & & $(89.84)$ & $(3.29)$ & $(0.92)$ & $(5.94)$ \\
\hline \multirow[t]{2}{*}{ 합계 } & 50,198 & 45,267 & 1,403 & 840 & 2,688 \\
\hline & & $(90.18)$ & $(2.79)$ & (1.67) & $(5.35)$ \\
\hline \multicolumn{6}{|c|}{$\mathrm{B}$ : 개별펀드 } \\
\hline \multirow[t]{2}{*}{2013} & 86,725 & 82,066 & 555 & 3,939 & 166 \\
\hline & & (94.63) & $(0.64)$ & $(4.54)$ & $(0.19)$ \\
\hline \multirow[t]{2}{*}{2014} & 84,943 & 79,076 & 780 & 3,433 & 1,654 \\
\hline & & (93.09) & $(0.92)$ & $(4.04)$ & (1.95) \\
\hline \multirow[t]{2}{*}{2015} & 96,397 & 91,079 & 1,425 & 2,509 & 1,385 \\
\hline & & (94.48) & (1.48) & $(2.60)$ & (1.44) \\
\hline \multirow[t]{2}{*}{2016} & 70,828 & 65,350 & 886 & 3,053 & 1,539 \\
\hline & & (92.27) & $(1.25)$ & (4.31) & (2.17) \\
\hline \multirow[t]{2}{*}{$2017^{*}$} & 49,593 & 45,641 & 1,776 & 1,232 & 944 \\
\hline & & (92.03) & (3.58) & (2.48) & (1.90) \\
\hline \multirow[t]{2}{*}{ 합계 } & 388,486 & 363,211 & 5,421 & 14,165 & 5,689 \\
\hline & & (93.49) & (1.40) & $(3.65)$ & (1.46) \\
\hline
\end{tabular}

주) *9월 말 현재

8) 동일 집합투자업자가 찬성과 동시에 반대, 중립, 불행사를 행사하는 경우 가장 높은 비율의 의결권 종류로 집계했다. 
Impact of Asset Management Companies' Exercise of Voting Rights on Corporate Value

밝혀졌다. 반대의결권 비율은 2013년 1.47\%에 불과했으나 2016년과 2017년에는 $3 \%$ 를 상회하였다. 반대의결권 비율의 증가 추세는 <그림 $1>$ 에 상세히 나타나 있다. 반면 찬성비율은 2016년 이후 80\%대로 하락하였다. 한편 중립비율은 지속적으로 감소하고 있다.

이 같은 수치는 $\operatorname{Kim}$ and $\operatorname{Yon}(2014)$ 이 2005년부터 2011년까지의 조사에서 밝힌 집합투자 업자의 의결권 찬성율 $97.4 \%$, 반대율 $0.85 \%$, 중립율 $0.92 \%$, 불행사율 $0.84 \%$ 와 상당한 차이를 보이는 것으로 최근 집합투자업자들이 과거보다 의결권행사에 적극적으로 임하는 것으로 해석할 수 있다. 또한 대신경제연구소가 2016년 정기 주총 시 파악한 집합투자업자가 행사한 의결권 비율9)에 비해서도 찬성비율은 소폭 낮아진 반면 반대비율은 대폭 높아졌다. 이는 집합투자업자가 정기 주총에서 보다 임시주총에서 의결권을 보다 적극적으로 행사했기 때문으로 추론할 수 있다.

이를 개별펀드 기준으로 구분하면 집합투자업자 기준에 비해 반대율과 불행사율은 낮아지는 반면 찬성율과 중립율은 높아진다. 이는 반대나 불행사 의결권의 경우 집합투자업자가 통일된 집중적인 의사표명을 하기 때문으로 풀이된다. 특히 반대의결권의 경우 2017년 $3.58 \%$ 를 기록, 이전 연도보다 두 배 이상 증가해 개별 펀드별로는 반대 의결권을 적극적으로 개진한 것으로 드러났다. 한편 집합투자업자 기준에 비해 중립율은 높은 반면 불행사율은 훨씬 더 낮았다.

〈그림 1〉연도별 의결권 반대행사 비율 추이

(단위: \%)

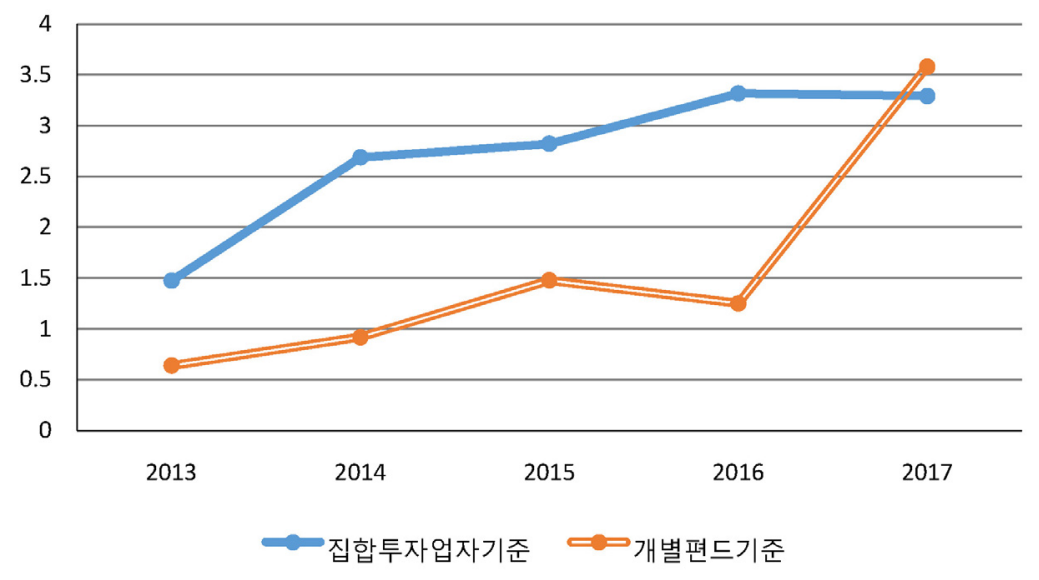

집합투자업의 안건별 의결권 행사 내역은 <표 2>에 정리되어 있다. 10 < 표 2>에서 보는 바와 같이 안건별로 다소 상이하게 의결권을 행사하고 있는 것으로 나타났다. 이익배당이나

9) 대신경제연구소는 당초 행사한 총 의결권 대비 각 의결권의 비율을 공지했지만 본 논문과 같이 총 안건 수 대비 각 의결권의 비율을 산출하면 찬성 $92.4 \%$, 반대 $2.1 \%$, 중립 $1.4 \%$, 불행사 $4.1 \%$ 가 된다.

$10)<$ 표 2>에 기술된 안건 이외에 대표이사 변경(2건), 액면미달 신주발행(1건), 이익처분(143건), 자본감소 23 건, 주식분할(병합)(44건), 해산 청산 회사정리(2건) 등이 있다. 이 중 반대의결권 행사 건수는 없고 이익처분, 자본감소에서는 불행사가 각각 1 건과 3 건, 주식분할(병합)에서는 불행사와 중립이 2 건과 1 건을 기록했다. 
한국증권학회지 제48권 6호 (2019)

〈표 2〉 집합투자업자 및 개별펀드의 안건별 의결권 행사 내역

(괄호 안은 \%)

\begin{tabular}{|c|c|c|c|c|c|}
\hline & 총안건수 & 찬성 & 반대 & 중립 & 불행사 \\
\hline \multicolumn{6}{|l|}{$\mathrm{A}$ : 집합투자업자 } \\
\hline 정관변경 & 6,495 & $\begin{array}{r}6,004 \\
(92.44)\end{array}$ & $\begin{array}{r}176 \\
(2.71)\end{array}$ & $\begin{array}{r}113 \\
(1.74)\end{array}$ & $\begin{array}{r}202 \\
(3.11)\end{array}$ \\
\hline $\begin{array}{l}\text { 주식매수청구권 } \\
\text { (전환사채 증자 포함) }\end{array}$ & 615 & $\begin{array}{r}533 \\
(86.67)\end{array}$ & $\begin{array}{r}43 \\
(6.99)\end{array}$ & $\begin{array}{r}8 \\
(1.30)\end{array}$ & $\begin{array}{r}31 \\
(5.04)\end{array}$ \\
\hline 재무제표승인 & 11,780 & $\begin{array}{l}11,098 \\
(94.21)\end{array}$ & $\begin{array}{r}70 \\
(0.59)\end{array}$ & $\begin{array}{r}197 \\
(1.67)\end{array}$ & $\begin{array}{r}415 \\
(3.52)\end{array}$ \\
\hline 임원의 임면 & 12,436 & $\begin{array}{r}11,329 \\
(91.10)\end{array}$ & $\begin{array}{r}397 \\
(3.19)\end{array}$ & $\begin{array}{r}235 \\
(1.89)\end{array}$ & $\begin{array}{r}475 \\
(3.82)\end{array}$ \\
\hline 임원보수결정 & 12,037 & $\begin{array}{r}11,241 \\
(93.39)\end{array}$ & $\begin{array}{r}165 \\
(1.37)\end{array}$ & $\begin{array}{r}204 \\
(1.69)\end{array}$ & $\begin{array}{r}427 \\
(3.55)\end{array}$ \\
\hline 이익배당 & 237 & $\begin{array}{r}198 \\
(83.54)\end{array}$ & $\begin{array}{r}32 \\
(13.50)\end{array}$ & $\begin{array}{r}1 \\
(0.42)\end{array}$ & $\begin{array}{r}6 \\
(2.53)\end{array}$ \\
\hline 영업양수도 & 56 & $\begin{array}{r}43 \\
(76.79)\end{array}$ & $\begin{array}{r}5 \\
(8.93)\end{array}$ & $\begin{array}{r}3 \\
(5.36)\end{array}$ & $\begin{array}{r}5 \\
(8.93)\end{array}$ \\
\hline 합병(흡수 및 분할) & 784 & $\begin{array}{r}639 \\
(81.51)\end{array}$ & $\begin{array}{r}67 \\
(8.55)\end{array}$ & $\begin{array}{r}20 \\
(2.55)\end{array}$ & $\begin{array}{r}58 \\
(7.40)\end{array}$ \\
\hline 기타 & 5,543 & $\begin{array}{r}3,975 \\
(71.71) \\
\end{array}$ & $\begin{array}{r}447 \\
(8.06) \\
\end{array}$ & $\begin{array}{r}58 \\
(1.05) \\
\end{array}$ & $\begin{array}{r}1,063 \\
(19.18) \\
\end{array}$ \\
\hline \multicolumn{6}{|l|}{$\mathrm{B}$ : 개별펀드 } \\
\hline 정관변경 & 45,732 & $\begin{array}{l}44,120 \\
(96.48)\end{array}$ & $\begin{array}{r}489 \\
(1.07)\end{array}$ & $\begin{array}{r}882 \\
(1.93)\end{array}$ & $\begin{array}{r}241 \\
(0.53)\end{array}$ \\
\hline $\begin{array}{l}\text { 주식매수청구권 } \\
\text { (전환사채 증자 포함) }\end{array}$ & 3,803 & $\begin{array}{r}3,545 \\
(93.21)\end{array}$ & $\begin{array}{r}103 \\
(2.70)\end{array}$ & $\begin{array}{r}102 \\
(2.68)\end{array}$ & $\begin{array}{r}53 \\
(1.40)\end{array}$ \\
\hline 재무제표승인 & 99,713 & $\begin{array}{r}98,059 \\
(98.34)\end{array}$ & $\begin{array}{r}91 \\
(0.09)\end{array}$ & $\begin{array}{l}1,019 \\
(1.02)\end{array}$ & $\begin{array}{r}544 \\
(0.55)\end{array}$ \\
\hline 임원의 임면 & 106,641 & $\begin{array}{r}103,875 \\
(97.41)\end{array}$ & $\begin{array}{l}1,145 \\
(1.07)\end{array}$ & $\begin{array}{l}1,071 \\
(1.00)\end{array}$ & $\begin{array}{r}549 \\
(0.52)\end{array}$ \\
\hline 임원보수결정 & 102,852 & $\begin{array}{r}100,797 \\
(98.00)\end{array}$ & $\begin{array}{r}494 \\
(0.48)\end{array}$ & $\begin{array}{r}1,003 \\
(0.98)\end{array}$ & $\begin{array}{r}558 \\
(0.54)\end{array}$ \\
\hline 이익배당 & 914 & $\begin{array}{r}714 \\
(78.07)\end{array}$ & $\begin{array}{r}152 \\
(16.68)\end{array}$ & $\begin{array}{r}9 \\
(0.98)\end{array}$ & $\begin{array}{r}39 \\
(4.27)\end{array}$ \\
\hline 영업양수도 & 507 & $\begin{array}{r}415 \\
(81.93)\end{array}$ & $\begin{array}{r}25 \\
(4.93)\end{array}$ & $\begin{array}{r}48 \\
(9.47)\end{array}$ & $\begin{array}{r}19 \\
(3.67)\end{array}$ \\
\hline 합병(흡수 및 분할) & 7,374 & $\begin{array}{r}6,052 \\
(82.08)\end{array}$ & $\begin{array}{r}421 \\
(5.71)\end{array}$ & $\begin{array}{r}366 \\
(4.97)\end{array}$ & $\begin{array}{r}535 \\
(7.25)\end{array}$ \\
\hline 기타 & 18,923 & $\begin{array}{r}16,190 \\
(85.56)\end{array}$ & $\begin{array}{r}703 \\
(3.72)\end{array}$ & $\begin{array}{r}435 \\
(2.30)\end{array}$ & $\begin{array}{l}1,595 \\
(8.43)\end{array}$ \\
\hline
\end{tabular}


Impact of Asset Management Companies' Exercise of Voting Rights on Corporate Value

영업양수도, 합병과 관련해서는 다른 안건에 비해 반대의견이 압도적으로 많았다. 특히 이익 배당의 경우 반대비율이 $13.5 \%$ 로 상당히 높게 나타났다. 반면 재무제표 승인은 반대비율이 $0.59 \%$ 에 그쳐 대조를 보였으며 임원보수 결정에도 별다른 반대의사를 표명하지 않는 것으로 조사됐다. 한편 의결권을 행사하지 않는 불행사 안건은 기타 안건이 $19.18 \%$ 로 가장 높게 나타났다. 기타 안건의 경우 대부분 해외 기업에 대한 의결권으로 물리적으로 행사하기 어려웠기 때문으로 풀이된다.

개별펀드의 안건별 의결권 행사도 집합투자업자의 행사 패턴과 유사하게 나타났다. 다만 이익배당의 경우 반대비율이 $16.68 \%$ 로 집합투자업자에 비해 월등히 높았으며 중립비율 중에서는 영업양수도가 $9.47 \%$ 로 가장 높게 나타났다. 재무제표 승인과 임원보수 결정에 대해서는 집합투자업자와 유사하게 찬성비율이 다른 안건에 비해 상대적으로 높아 $98 \%$ 대를 기록했다.

한편 의결권 행사기업의 주가수익률 자료는 Data Guide를 활용하여 확보하였다. 대규모 기업집단과 관련된 자료는 공정거래위원회의 기업집단포털을 활용했으며 이를 통해 대규모 기업집단 소속 집합투자업자들을 구분하였다.

\section{2 방법론}

집합투자업자가 행사한 반대 의결권에 대한 기업가치 평가는 다음 식 (1)과 같이 시장조정 수익률 모형을 통해 초과수익률 $(A R)$ 과 누적초과수익률 $(C A R)$ 을 산출한다.

$$
\begin{aligned}
& A R_{i, t}=R_{i, t}-R_{m, t} \\
& C A R_{i}\left[\tau_{1}, \tau_{2}\right]=\sum_{t=\tau_{1}}^{\tau_{2}}, A R_{i, t}
\end{aligned}
$$

$\tau$ 는 의결권 행사가 주가에 영향을 미칠만한 주요 일자 위주로 구분된다. 먼저 자본시장법에서는 주총 소집통지 기한을 주총 최소 2 주 전으로 정하고 있으므로 주총 개최 후 5 일 이내에 의결권 행사를 공시하게 되어 있었으므로 주총일 기준 +5 일도 주요 일자로 간주한다.11) 이와 함께 국민연금의 경우 주총 후 14 일 이내에 의결권행사내역을 홈페이지에 공시하게 행사지침에 규정, 집합투자업자들이 이를 원용하는 경우 이 또한 주요일자가 될 수 있다. 따라서 이벤트윈도우는 주총일 기준 -14 일부터 +14 일이 되며 이벤트윈도우 중 주요일자를 기준으로 누적초과수익률을 각각 산출한다. 즉 우선 이벤트윈도우 전체 기간 $(-14,14)$ 에 대한 누적초과수익률을 살펴보고 주총 소집통기 기한과 주총일 $(-14,0)$ 간, 주총일과 국민연금의 의결권행사내역 공시기간 $(0,14)$ 동안의 누적초과수익률을 산출한다. 또한 집합투자업자들의 의결권 공시기간이 주총 개최 후

11) 집합투자업자의 의결권 공시 규정은 지속적으로 변경되어 왔다. 2013년 2월 이전에는 주주총회 5 일 전에 의결권 행사여부 및 그 내용을 공시하게 되어 있었으나 이후에는 규정이 개정되면서 주총 개최 후 5 일 이내 공시로 변경되었다. 하지만 2015년 10 월 자본시장법이 개정되면서 집합 투자업자의의결권 행사 내역 공시가 연 1회로 다시 변경되었다. 이 같은 공시 규제 완화는 의결권 행사 사유를 포함시킴에 따라 공시내용의 충실성은 확보할 수 있는 반면 시장 감시를 위한 적시성은 악화시키는 것으로 분석되고 있다. 
한국증권학회지 제48권 6호 (2019)

5 일임을 감안, 주총일 기준 전후 5 일 $(-5,5)$ 과 주총일 이후 5 일 $(0,5)$ 동안의 누적초과수익률도 분석한다.

표본기업 전체에 대한 $t$ 일의 평균초과수익률 $A R_{N t}$ 와 $\tau_{1}$ 에서 $\tau_{2}$ 까지의 누적 평균초과수익률 $C A R_{N \cdot t}$ 는 다음 식 (2)를 통해 산출된다.

$$
\begin{aligned}
& A R_{N, t}=\frac{1}{N} \sum_{i=1}^{N} A R_{i, t} \\
& C A R_{N}\left[\tau_{1}, \tau_{2}\right]=\sum_{t=\tau_{1}}^{\tau_{2}}, A R_{N, t}
\end{aligned}
$$

\section{4. 연구결과}

\section{1 집합투자업자의 의결권 반대행사에 대한 시장반응}

\subsection{1 일자별}

의결권 행사 중 반대의결권을 공시한 것은 1,403 건이다. 이 중 해당기업이 외국기업이거나 비상장기업은 제외했다. 또한 주가자료나 재무제표 자료가 존재하지 않는 기업도 제외했다. 이에 따라 최종 분석대상으로 822 건이 도출되었다. 해당기업은 총 290 개이고 집합투자업자는 총 47 개사에 달했다.

또한 동일 집합투자업자가 특정기업의 특정안건에 대해 행사한 복수의 의결권을 단수화하면 (이하 기업 및 운용사 기준) 표본 수는 697 개가 되며 특정기업의 특정안건에 대해 복수의 집합투자업자가 행사한 의결권을 단수화하면(이하 기업기준) 표본 수는 472 개가 된다. 즉 기업 및 운용사 기준은 동일 집합투자업자가 행사한 특정기업의 특정안건을 하나로 간주한 것이며, 기업기준은 기업 입장에서 동일한 안건에 대해 행사한 의결권을 하나로 간주한 것이다.

이들 전체표본과 기업 및 운용사 기준, 그리고 기업기준의 반대 의결권 행사 기준 -14 일부터 14 일까지의 평균초과수익률 및 평균누적초과수익률은 <표 3>에 정리되어 있다.

집합투자업자가 반대 의결권을 행사하는 당일(0) 기업들의 주가는 상승하여 통계적으로 유의한 양의 초과수익률 $(\mathrm{AR})$ 을 기록하는 것으로 밝혀졌다. 또한 기업 및 운용사기준, 기업기준에서도 모두 양의 초과수익률을 시현했으며 특히 특정 기업의 동일 안건에 대한 복수의 집합투자업자의 의결권을 하나로 간주한 기업기준의 경우 $0.25 \%$ 로 가장 높은 수익률을 보였다. 이는 집합투자 업자가 반대의결권을 행사하는 경우 시장은 긍정적으로 반응한다는 의미로 시사하는 바가 크다고 할 수 있다. 또한 주총일 이후 4 일 $(+4)$ 과 5 일 $(+5)$ 에서도 통계적으로 유의한 양의 초과수익률을 기록했다. 이는 표본기간 중 공시규정이 주총 후 5 일 이내로 변경됨에 따라 기업들이 주로 주총 후 4 일 또는 5 일에 의결권 행사내역을 공시, 시장에서 이를 새로운 정보로 인식하여 반응한 것으로 풀이할 수 있다.

반면 주총일 이전 4 일 $(-4)$ 부터 주총일 당일까지는 일별 초과수익률이 음수를 보였다. 전체 표본의 경우 주총일 4 일 전(-4)부터 2 일 전(-2)까지 유의한 음의 초과수익률을 기록했으며 
Impact of Asset Management Companies' Exercise of Voting Rights on Corporate Value

기업 및 운용사 기준에서는 주총일 4 일 전(-4)과 3 일 전(-3), 기업기준에서는 주총일 3 일(-3) 전에 초과수익률이 마이너스였다. 또한 주총 9 일 전(-9)에도 주가는 하락했다. 전반적으로 전체표본보다는 기업 및 운용사 기준이, 기업 및 운용사 기준보다는 기업기준의 초과수익률이 소폭 높게 나타났다.

〈표 3〉 집합투자업자의 의결권 반대행사에 대한 시장반응

*** ${ }^{* *},{ }^{*}$ 는 각각 $1 \%, 5 \%, 10 \%$ 수준에서 유의함을 의미함.

(단위 \%)

\begin{tabular}{|c|c|c|c|c|c|c|}
\hline 구분 & \multicolumn{2}{|c|}{ 전체 } & \multicolumn{2}{|c|}{ 기업 및 운용사 기준 } & \multicolumn{2}{|c|}{ 기업 기준 } \\
\hline 표본수 & \multicolumn{2}{|c|}{822} & \multicolumn{2}{|c|}{697} & \multicolumn{2}{|c|}{472} \\
\hline & $\mathrm{AR}$ & CAR & $\mathrm{AR}$ & CAR & $\mathrm{AR}$ & CAR \\
\hline-14 & 0.0707 & 0.0707 & 0.0162 & 0.0162 & -0.0803 & -0.0803 \\
\hline-13 & 0.0283 & 0.0990 & 0.0434 & 0.0596 & 0.0307 & -0.0495 \\
\hline-12 & -0.0884 & 0.0106 & -0.0824 & -0.0228 & $-0.1660^{*}$ & -0.2155 \\
\hline-11 & 0.1009 & 0.1115 & 0.0817 & 0.0589 & 0.1219 & -0.0937 \\
\hline-10 & -0.0788 & 0.0326 & -0.1149 & -0.0560 & -0.0130 & -0.1067 \\
\hline-9 & $-0.2967^{* * *}$ & $-0.2641^{*}$ & $-0.2736^{* * *}$ & $-0.3296^{*}$ & $-0.2183^{* *}$ & -0.3250 \\
\hline-8 & -0.0633 & $-0.3273^{*}$ & -0.0697 & $-0.3993^{* *}$ & -0.0468 & -0.3717 \\
\hline-7 & 0.0402 & -0.2872 & -0.0489 & $-0.4482^{* *}$ & -0.1086 & $-0.4803^{*}$ \\
\hline-6 & $0.1724^{* *}$ & -0.1148 & $0.1882^{* *}$ & -0.2600 & 0.1362 & -0.3442 \\
\hline-5 & $0.1338^{*}$ & 0.0190 & $0.1389^{*}$ & -0.1211 & 0.1394 & -0.2047 \\
\hline-4 & $-0.3438^{* * *}$ & -0.3248 & $-0.2413^{* * *}$ & -0.3625 & -0.1432 & -0.3479 \\
\hline-3 & $-0.2159^{* * *}$ & $-0.5406^{* *}$ & $-0.2297^{* * *}$ & $-0.5922^{* *}$ & $-0.2249^{* *}$ & -0.5728 \\
\hline-2 & $-0.1425^{* *}$ & $-0.6831^{* * *}$ & -0.1091 & $-0.7013^{* *}$ & -0.1167 & $-0.6895^{* * *}$ \\
\hline-1 & 0.0797 & $-0.6034^{* *}$ & 0.1190 & $-0.5823^{* *}$ & 0.0959 & -0.5936 \\
\hline 0 & $0.1677^{* *}$ & -0.4357 & $0.1863^{* *}$ & -0.3960 & $0.2504^{* *}$ & -0.3432 \\
\hline 1 & $-0.2518^{* * *}$ & $-0.6157^{* *}$ & $-0.2344^{* * *}$ & $-0.5635^{*}$ & $-0.2257^{* *}$ & -0.5547 \\
\hline 2 & $0.1636^{* *}$ & -0.4520 & $0.1304^{*}$ & -0.4331 & 0.0904 & -0.4643 \\
\hline 3 & 0.0081 & -0.4440 & 0.0400 & -0.3930 & 0.0463 & -0.4181 \\
\hline 4 & $0.1439^{*}$ & -0.3000 & $0.1369^{*}$ & -0.2562 & $0.2057^{* *}$ & -0.2124 \\
\hline 5 & $0.2819^{* *}$ & -0.0182 & $0.3001^{* * *}$ & 0.0439 & $0.3761^{* * *}$ & 0.1638 \\
\hline 6 & 0.0479 & 0.0297 & 0.0872 & 0.1312 & 0.1126 & 0.2764 \\
\hline 7 & $-0.1377^{* *}$ & -0.1079 & -0.1042 & 0.0269 & -0.0248 & 0.2516 \\
\hline 8 & 0.0430 & -0.0649 & 0.0351 & 0.0620 & 0.0164 & 0.2679 \\
\hline 9 & -0.0158 & -0.0807 & -0.0378 & 0.0242 & -0.0011 & 0.2668 \\
\hline 10 & $0.3158^{* * *}$ & 0.2350 & $0.2875^{* * *}$ & 0.3117 & $0.3229^{* * *}$ & 0.5897 \\
\hline 11 & $-0.3227^{* * *}$ & -0.0877 & $-0.2966^{* * *}$ & 0.0151 & $-0.2829^{* * *}$ & 0.3068 \\
\hline 12 & -0.0058 & -0.0934 & 0.0311 & 0.0461 & 0.0040 & 0.3109 \\
\hline 13 & 0.0994 & 0.0059 & 0.1021 & 0.1482 & 0.0174 & 0.3282 \\
\hline 14 & $-0.2023^{* * *}$ & -0.1964 & -0.1086 & 0.0396 & 0.1080 & 0.4362 \\
\hline
\end{tabular}

누적초과수익률 $(\mathrm{CAR})$ 의 경우 주총일을 전후하여 음의 수익률을 기록했다. 이는 Kim and Yon(2014)의 주총일 7일 전(-7)부터 양의 누적초과수익률을 보인다는 연구와 정반대의 결과로 
한국증권학회지 제48권 6호 (2019)

주목할 만하다. 그들은 2005년부터 2011년 사이의 표본을 대상으로 분석을 실시, 해당 기간 중에는 의결권 행사 내용을 주총 5 일 전까지 공시하게 되어있었던 반면 본 연구의 표본기간 중에는 공시규정이 주총 개최 후 5 일 이내로 변경되었기 때문에 연구결과가 다르게 도출된 것으로 유추할 수 있다. 또한 그들은 기업의 동일안건에 대한 복수 의결권이나 동일 집합투자업자에 의해 행사되는 복수 의결권을 고려하지 않고 분석을 시행한 것도 상이한 결과를 도출하게 된 이유로 추론할 수 있다.

이 같은 누적초과수익률의 일자별 변동추이는 <그림 $2>$ 에 보다 상세히 나타나있다. 누적초과 수익률은 주총 소집통지 기한인 주총 14 일 전(-14)부터 주총 5 일 전까지 소폭 감소와 증가를 반복하다가 주총 5 일 전 양의 수익률로 전환된 후 급격히 하락, 주총 2 일 전 최대 음의 수익률을 기록한다. 이후 주총일에 반짝 상승한 누적초과수익률은 주총 다음날 소폭 하락하다 상승세로 전환, 주총 5 일 후부터 급격하게 증가하며 양의 수익률로 전환된다. 즉 주총 5 일 전 $(-5)$ 부터 주총 5 일 후 $(+5)$ 까지 누적초과수익률은 $\omega$ 형태를 시현한다고 볼 수 있다. 이 같이 주총 전 3 일과 4 일에 음의 초과수익률을 기록한 것은 Kim and Yon(2014)과 동일한 결과이다. 다만 의결권 행사 공시일이 주총 전 5일에서 주총 후 5일 이내로 변경됨에 따라 Kim and Yon(2014)의 연구결과와는 달리 음의 누적초과수익률을 보인 것으로 추론된다. 전체표본과 기업 및 운용사기준, 기업기준을 비교하면 기업기준이 다른 표본에 비해 변동 폭이 더 큰 것으로 나타났다. 즉 기업기준이 주총 5 일 전까지는 가장 낮은 음의 누적초과수익률을 보이다 주총 5 일 후부터는 가장 높은 양의 누적초과수익률로 전환된다. 이는 전체 표본의 경우 동일안건에 대해 복수의 의결권을 모두 고려함에 따라 수치의 평활화가 이루어졌기 때문으로 풀이된다.

〈그림 2〉의결권 반대행사에 따른 누적수익률 추이

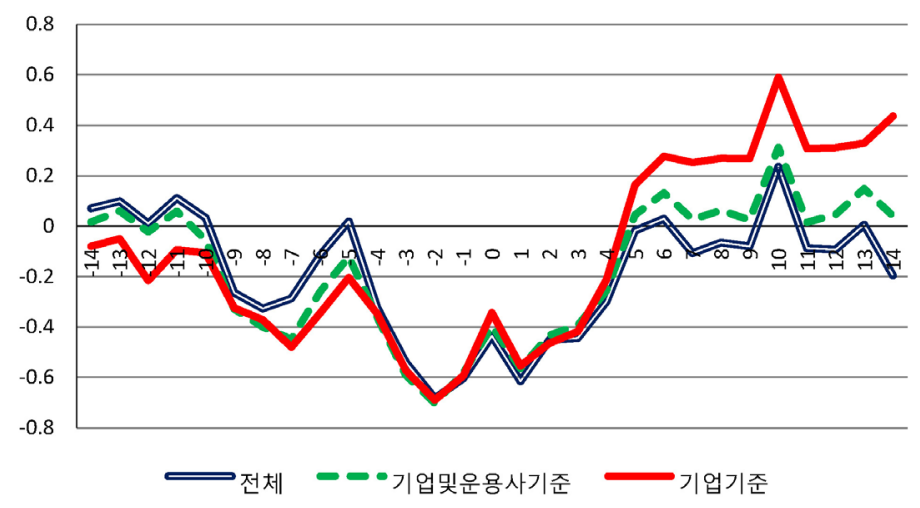

\subsection{2 연도별}

집합투자업자의 의결권 반대행사에 따른 시장반응은 <표 $4>$ 에 정리되어 있다. 전체 표본에 대한 분석결과 주총일부터 주총 5 일 후까지 통계적으로 유의한 $1.41 \%$ 의 누적초과수익률을 기록했다. 이 같은 양의 누적초과수익률은 기업 및 운용사 기준이나 기업기준의 경우 주총일부터 주총 14 일 후까지의 기간에서도 유의하게 나타났다. 이는 집합투자업자가 의결권 행사를 주총 
Impact of Asset Management Companies' Exercise of Voting Rights on Corporate Value

후 5 일까지 공시하거나 또는 그 이후 짧은 미래에 공시하기 때문으로 유추된다. 이 같은 결과는 집합투자업자의 반대 의결권 행사는 시장에서 긍정적으로 평가하여 공시 시점에 이를 정보효과로 인식하는 것으로 풀이할 수 있다. 반면 주총 14 일 전부터 주총일까지는 유의하지는 않지만 음의 수익률을 보였다.

〈표 4〉 집합투자업자의 의결권 반대행사에 대한 연도별 시장반응 ***, **, *는 각각 $1 \%, 5 \%, 10 \%$ 수준에서 유의함을 의미함.

(단위 \%)

\begin{tabular}{|c|c|c|c|c|c|c|}
\hline & 표본 수 & $\operatorname{CAR}(-14,0)$ & $\operatorname{CAR}(-5,5)$ & $\operatorname{CAR}(0,5)$ & $\operatorname{CAR}(0,14)$ & $\operatorname{CAR}(-14,14)$ \\
\hline \multicolumn{7}{|l|}{$\mathrm{A}$ : 전체 } \\
\hline 2013 & 84 & -0.57 & 0.41 & 0.79 & 1.28 & 1.72 \\
\hline 2014 & 133 & $2.79^{* * *}$ & -0.58 & 0.26 & -0.42 & $1.65^{* *}$ \\
\hline 2015 & 169 & $-1.50^{* *}$ & 0.54 & 0.05 & -0.06 & -1.22 \\
\hline 2016 & 178 & 0.07 & -0.80 & -0.23 & -0.21 & -0.30 \\
\hline 2017 & 258 & $-1.70^{* * *}$ & $0.76^{* * *}$ & $1.41^{* * *}$ & $1.15^{* * *}$ & $-0.87^{*}$ \\
\hline 전체기간 & 822 & -0.44 & 0.12 & $0.52^{* * *}$ & 0.34 & -0.20 \\
\hline \multicolumn{7}{|c|}{ B: 기업 및 집합투자업자 기준 } \\
\hline 2013 & 67 & 0.16 & 0.48 & 0.42 & 0.99 & 2.32 \\
\hline 2014 & 109 & $2.07^{* * *}$ & -0.53 & 0.17 & -0.05 & $1.43^{*}$ \\
\hline 2015 & 151 & $-1.13^{*}$ & 0.75 & 0.12 & -0.04 & -0.89 \\
\hline 2016 & 149 & 0.13 & -0.41 & -0.03 & 0.23 & 0.14 \\
\hline 2017 & 221 & $-1.63^{* * *}$ & $0.88^{* *}$ & $1.51^{* * *}$ & $1.40^{* * *}$ & -0.62 \\
\hline 전체기간 & 697 & -0.40 & 0.31 & $0.57^{* * *}$ & $0.56^{*}$ & 0.04 \\
\hline \multicolumn{7}{|c|}{ C: 기업기준 } \\
\hline 2013 & 43 & 0.22 & -0.74 & -0.19 & -0.47 & 0.03 \\
\hline 2014 & 71 & 1.52 & -0.84 & -0.17 & -0.56 & 0.53 \\
\hline 2015 & 104 & -0.39 & $2.03^{*}$ & $1.38^{*}$ & $1.78^{*}$ & 1.03 \\
\hline 2016 & 115 & -0.07 & -0.11 & 0.18 & 0.69 & 0.68 \\
\hline 2017 & 138 & $-1.67^{* * *}$ & $0.95^{*}$ & $1.48^{* * *}$ & $1.97^{* * *}$ & -0.14 \\
\hline 전체기간 & 471 & -0.34 & 0.51 & $0.75^{* * *}$ & $1.02^{* * *}$ & 0.44 \\
\hline
\end{tabular}

집합투자업자의 의결권 반대행사에 따른 시장반응을 연도별로 분석한 결과, 2017년이 가장 강하게 반응한 것으로 조사됐다. 2017 년에는 $\operatorname{CAR}(0,5)$ 뿐 아니라 $\operatorname{CAR}(0,14), \operatorname{CAR}(-5$, 5)에서도 $1 \%$ 내외의 양의 수익률을 기록했다. 반면 주총 14 일 전부터 주총일까지는 음의 수익률을 보였다. 이 같은 결과는 투자자들이 최근 기관들의 의결권 행사에 대한 관심이 높아지면서 집합투자업자들의 의결권 반대 행사에 대해 모니터링하고 있는 것으로 해석할 수 있다. 또한 2015년에는 기업기준의 경우에만 $\operatorname{CAR}(-5,5), \operatorname{CAR}(0,5), \operatorname{CAR}(0,14)$ 가 양의 누적초과수익률을 기록했다. 한편 2014년에는 주총 14일 이전부터의 누적초과수익률이 양수를 기록, 다소 의외의 결과를 보였다. 이는 2013년 변경된 의결권 공시규정이 전환되는 과정에서 과거와 같이 주총일 이전에 반대 의결권을 공시했을 가능성 때문으로 생각된다. 


\subsection{3 안건별}

안건별 반대의견에 대한 시장반응 결과는 <표 $5>$ 에 정리되어 있다. 분석결과 시장은 안건에 따라 반응이 상이하게 나타났다. 흡수나 분할 등 합병과 관련되어 반대하는 경우에는 양의 누적초과수익률을 시현했다. 전체 표본의 경우 주총일부터 주총 5 일 후까지 합병반대 의결권 행사에 대한 누적초과수익률은 $2.51 \%$ 를 기록했다. 또한 임원임명에 대한 반대 의결권 행사도 시장에서는 긍정적으로 받아들이는 것으로 밝혀졌다.

반면 이익배당의 경우에는 반대 의결권 행사에 대해 시장은 부정적으로 반응했다. 전체 표본을 대상으로 분석한 결과 주총일 이후 5 일까지의 누적초과수익률은 $-7.79 \%$ 를 기록했다. 또한 주총 5 일 전부터 5 일 후까지의 누적초과수익률도 음수를 보였다. 영업양수도나 정관변경의 경우에도 반대 의결권 행사에 대해 시장은 부정적으로 인식했다. 정리하면 시장은 임원임명, 합병, 재무제표 승인에 대한 반대 의결권에는 긍정적인 반응을, 정관변경, 이익배당, 영업양수도에 대한 반대 의결권 행사에는 부정적인 반응을 보인 셈이다.

특정기업의 동일안건에 대해 집합투자업자들이 행사한 반대의결권을 하나로 간주한 기업기준의 경우에는 전체 표본에 비해 시장반응이 전반적으로 약하게 나타났다. 합병과 임원임명에 대한 반대 의결권은 긍정적, 정관변경에 대해서는 부정적인 시장반응 정도가 유의하게 도출되었다.

〈표 5〉 집합투자업자의 의결권 반대행사에 대한 안건별 시장반응 ***, **, *는 각각 $1 \%, 5 \%, 10 \%$ 수준에서 유의함을 의미함.

(단위: \%)

\begin{tabular}{lrccccc}
\hline & 표본 수 & $\mathrm{CAR}(-14,0)$ & $\mathrm{CAR}(-5,5)$ & $\mathrm{CAR}(0,5)$ & $\mathrm{CAR}(0,14)$ & $\mathrm{CAR}(-14,14)$ \\
\hline $\mathrm{A}$ : 전체 & \multicolumn{7}{c}{} & & & & \\
\hline 임원의 임면 & 345 & -0.14 & 0.40 & $0.51^{*}$ & $0.77^{*}$ & 0.54 \\
정관변경 & 166 & $-1.69^{* *}$ & -0.03 & 0.39 & -0.92 & $-2.55^{* * *}$ \\
임원보수 & 142 & -0.38 & -0.25 & 0.50 & $1.11^{*}$ & 0.60 \\
합병(흡수, 분할) & 64 & 1.05 & $2.39^{* * *}$ & $2.51^{* * *}$ & 0.88 & 1.88 \\
재무제표 승인 & 26 & -3.99 & -0.29 & $1.23^{*}$ & 1.50 & -2.26 \\
주식매수선택권 & 22 & 2.33 & -2.03 & -0.97 & -2.46 & -0.69 \\
이익배당 & 7 & 3.17 & $-2.91^{* *}$ & $-7.79^{* *}$ & $-10.65^{* * *}$ & -2.06 \\
영업양수도 & 5 & $-7.35^{*}$ & $-6.27^{* *}$ & -2.37 & -1.12 & -8.62 \\
기타 & 45 & 0.54 & -0.45 & 0.85 & 1.06 & 0.30 \\
\hline B: 기업기준 & & & & & & \\
\hline 임원의 임면 & 256 & -0.34 & 0.68 & $0.68^{*}$ & $0.94^{*}$ & 0.57 \\
정관변경 & 118 & $-1.70^{*}$ & 0.15 & 0.68 & -0.02 & $-1.95^{*}$ \\
임원보수 & 113 & -0.08 & -0.24 & 0.33 & 1.12 & 0.99 \\
합병(흡수, 분할) & 26 & -0.02 & 1.92 & $2.12^{*}$ & 1.91 & 1.51 \\
재무제표 승인 & 24 & -4.33 & -0.30 & 0.96 & 1.26 & -2.81 \\
주식매수선택권 & 19 & 2.84 & -1.80 & -1.09 & -2.65 & -0.50 \\
이익배당 & 3 & 1.56 & -2.59 & -3.44 & -5.65 & -1.05 \\
영업양수도 & 3 & -6.99 & -5.38 & -2.13 & -1.35 & -8.36 \\
기타 & 40 & 0.98 & -0.49 & 0.47 & 0.75 & 0.64 \\
\hline
\end{tabular}


Impact of Asset Management Companies' Exercise of Voting Rights on Corporate Value

\subsection{4 펀드 수별}

집합투자업자는 특정안건에 대해 다수의 펀드를 통해 의결권을 행사할 수 있다. 예컨대 동일 안건에 대해 특정 집합투자업자의 1 개 펀드가 의결권을 행사할 수도 있고 100 개의 펀드가 의결권을 행사할 수도 있다. 본 연구의 표본 중 집합투자업자가 동일 안건에 대해 의결권을 행사한 최소 펀드 수는 1 개이고 최대 펀드 수는 85 개이다. 따라서 특정기업의 특정안건에 대해 복수의 펀드를 통해 의결권을 행사하는 경우 집합투자업자는 본인의 의견을 보다 강하게 주장할 수 있을 것으로 생각된다. 펀드 수별로 반대의견에 따른 기업 주가의 시장반응을 살펴보는 것이 의미있는 이유이다.

〈표 6〉 펀드 수별 의결권 반대행사에 대한 시장반응

*** ** *는 각각 $1 \%, 5 \%, 10 \%$ 수준에서 유의함을 의미함.

(단위: \%)

\begin{tabular}{lcccccc}
\hline & 표본수 & $\mathrm{CAR}(-14,0)$ & $\mathrm{CAR}(-5,5)$ & $\mathrm{CAR}(0,5)$ & $\mathrm{CAR}(0,14)$ & $\mathrm{CAR}(-14,14)$ \\
\hline $\mathrm{A}:$ 전체 & \multicolumn{7}{c}{} & & & & \\
\hline 1 & 240 & 0.35 & 0.68 & $0.91^{* *}$ & $0.88^{*}$ & 0.76 \\
$2 \sim 5$ & 243 & -0.48 & -0.44 & 0.32 & -0.16 & -0.65 \\
$6 \sim 10$ & 170 & $-1.26^{* *}$ & -0.42 & 0.05 & 0.96 & -0.32 \\
$11 \sim 20$ & 87 & -0.81 & 0.44 & 0.68 & -0.11 & -0.93 \\
$21 \sim 50$ & 72 & $-1.77^{* * *}$ & -0.12 & 0.37 & $-1.22^{*}$ & $-2.58^{* * *}$ \\
50 이상 & 10 & $8.79^{* *}$ & 8.02 & 3.54 & 3.52 & 12.36 \\
\hline $\mathrm{B}:$ 기업기준 & & & & & & \\
\hline 1 & 95 & 0.44 & 1.10 & $1.29^{* *}$ & $2.40^{* * *}$ & $2.24^{*}$ \\
$2 \sim 5$ & 137 & 0.63 & 0.55 & 0.44 & 0.07 & 0.64 \\
$6 \sim 10$ & 104 & $-1.68^{*}$ & 0.01 & 0.48 & $2.12^{* *}$ & 0.18 \\
$11 \sim 20$ & 57 & -1.19 & -1.03 & 0.31 & -0.84 & $-2.45^{* *}$ \\
$21 \sim 50$ & 50 & -1.20 & 1.16 & $1.22^{*}$ & 1.05 & -0.27 \\
50 이상 & 28 & 0.49 & 2.26 & 1.46 & 0.58 & 1.47 \\
\hline
\end{tabular}

펀드 수별 의결권 반대행사에 대한 시장반응은 <표 6>에 정리되어 있다. 집합투자업자가 동일한 안건에 대해 의결공시를 한 펀드 수별로 1 개, $2 \sim 5$ 개, $6 \sim 10$ 개, $11 \sim 20$ 개, $21 \sim 50$ 개, 50 개 이상 등 6 그룹으로 구분하여 시장반응을 살펴보았다. 분석결과 예상과는 달리 집합투자 업자가 1 개 펀드에 대한 반대 의결권 행사 시 오히려 시장반응은 긍정적이었다. 1 개 펀드의 경우 $\operatorname{CAR}(0,5)$ 와 $\operatorname{CAR}(0,14)$ 에서 모두 $1 \%$ 가까운 양의 누적초과수익률을 기록했다. 반면 21 50개 펀드의 그룹에서는 주총 전 14 일부터 주총일까지, 주총일부터 주총 14 일 후까지, 그리고 주총전후 14 일간 음의 누적초과수익률을 보였다. $\operatorname{CAR}(0,5)$ 의 경우 전반적으로 펀드 수에 따라 누적초과수익률은 $U$ 자 형태를 보였다. 즉 집합투자업자가 단일 펀드 또는 50 개 이상의 다수 펀드에 대한 반대의결권 행사 시 시장은 긍정적으로 반영하는 것으로 나타났다. 
한국증권학회지 제48권 6호 (2019)

기업기준 의결권 행사에 따른 시장반응에서도 전체표본을 대상으로 한 결과와 유사한 결과를 도출했다. 다만 21 50개 펀드의 경우 주총일부터 주총 5일 후까지 통계적으로 유의한 양의 누적초과수익률은 기록했다. 기업기준으로 동일 안건의 의결권에 대한 펀드 수 산출 시 최대 펀드 수는 250 개이다.

\subsection{5 의결권 수별}

집합투자업자가 보유한 펀드의 의결권 수는 다양하다. 기업 의결권에 대해 1 주를 보유한 펀드가 있는가 하면 1 백만주 이상을 보유한 펀드도 있다. 본 연구에서 활용한 표본 중에서 최소 반대 의결권 수는 1 주, 최대 반대 의결권 수는 4,359,224주였다. 따라서 집합투자업자가 행사하는 반대 의결권 수에 따라서도 시장반응은 상이하게 나타날 수 있다.12)

〈표 7〉의결권 수별 반대행사에 대한 시장반응

*** **, *는 각각 $1 \%, 5 \%, 10 \%$ 수준에서 유의함을 의미함.

(단위: \%)

\begin{tabular}{lcccccc}
\hline & 표본수 & $\mathrm{CAR}(-14,0)$ & $\mathrm{CAR}(-5,5)$ & $\mathrm{CAR}(0,5)$ & $\mathrm{CAR}(0,14)$ & $\mathrm{CAR}(-14,14)$ \\
\hline $\mathrm{A}$ : 전체 & 77 & $1.36^{*}$ & 0.56 & 0.64 & -0.22 & 0.64 \\
\hline 1천주 이하 & 140 & -0.79 & 0.11 & $0.93^{*}$ & $1.23^{* *}$ & 0.16 \\
1천주 1만주 & 168 & -0.58 & $-0.70^{*}$ & -0.05 & -0.96 & $-1.66^{* *}$ \\
1만주 5만주 & 102 & -0.12 & $1.18^{*}$ & $1.14^{*}$ & 0.33 & 0.33 \\
5만주 10만주 & 102 & 0.17 & 0.33 & $0.84^{*}$ & 0.11 \\
10만주 100만주 & 287 & $-0.73^{*}$ & -0.20 & 1.00 & 0.33 & -0.33 \\
100만주 이상 & 48 & -0.69 & & & & \\
\hline B: 기업기준 & & & & & & \\
\hline 1천주 이하 & 28 & 0.70 & $2.38^{*}$ & $1.40^{*}$ & 2.47 & 2.40 \\
1천주 1만주 & 55 & -0.35 & 1.38 & $1.33^{*}$ & 2.00 & 1.23 \\
1만주 5만주 & 78 & -1.18 & $-1.42^{* *}$ & -0.17 & 0.15 & -1.12 \\
5만주 10만주 & 58 & 1.17 & 1.29 & 0.95 & 0.72 & 1.33 \\
10만주 100만주 & 205 & -0.66 & 0.79 & $1.04^{* *}$ & $1.24^{* *}$ & 0.42 \\
100만주 이상 & 47 & -0.05 & -0.57 & -0.34 & -0.14 & -0.11 \\
\hline
\end{tabular}

반대 의결권 수에 따른 시장반응은 <표 $7>$ 에 정리되어 있다. 표본을 반대의 의결권 수에 따라 1 천주 이하, 1 천주 1 만주, 1 만주 5 만주, 5 만주 10 만주, 10 만주 100 만주, 100 만주 이상 등 6 개 그룹으로 구분하였다. 분석결과 의결권 수에 따라 시장반응은 일정한 패턴을 보이지 않는 것으로 드러났다. 즉 누적초과수익률 산출 기간에 따라 의결권 수별로 다소 상이한 결과를 보였다. 다만 주총일부터 주총 5 일 후까지의 경우 1 천주 1 만주, 5 만주 10 만주의 반대 의결권을 행사한 경우 양의 누적초과수익률을 기록했다. 주총일부터 주총 10 일 후까지의 누적초과수익률 에서도 1 천주 1 만주와 10 만주 100 만주의 반대의결권을 행사한 경우 시장반응은 긍정적인

12) 반대의결권 행사비율이 더 의미있는 지표일 수 있겠지만 전체 의결권 수를 파악하지 못해 반대의결권 수로 대체하였다. 
Impact of Asset Management Companies' Exercise of Voting Rights on Corporate Value

것으로 나타났다. 반면 1 만주 5 만주의 경우에는 $\operatorname{CAR}(-5,5), \operatorname{CAR}(-14,14)$ 에서 음의 누적초과 수익률을 기록했다.

기업기준을 대상으로 한 분석에서도 결과는 유사, 1 천주 이하, 1 천주 1 만주, 10 만주 100 만주의 반대의결권을 행사한 경우 시장반응은 긍정적인 것으로 나타났다. 특히 주총일부터 주총 5 일 후까지의 누적초과수익률은 의결권 수에 따라 100 만주 이상을 제외하고는 $U$ 자 형태의 누적초과수익률 패턴을 시현했다. 기업기준 최대 반대의결권 수는 $7,711,653$ 주였다.

\section{1 .6 정기주총 또는 임시주총}

집합투자업자들은 의결권을 정기주총 또는 임시주총에서 행사할 수 있다. 재무제표 승인이나 이익배당 등은 정기주총에서 논의될 의제이지만 임원임명이나 흡수합병, 영업양수도, 정관변경과 같은 일회성 이벤트는 임시주총에서 논의되는 경우가 일반적이다. 따라서 반대 의결권을 정기주총 또는 임시주총 중 어디에서 행사하는가에 따라 시장반응은 상이하게 나타날 수 있다.

정기주총 여부에 따른 의결권 반대행사에 대한 시장의 반응은 <표 8>에 정리되어 있다. 분석결과 임시주총과 정기주총의 의결권 행사에 대한 시장반응은 판이하게 상이한 것으로 밝혀졌다. 정기주총의 경우 $\operatorname{CAR}(0,5), \operatorname{CAR}(0,14)$ 등에서 강한 양의 누적초과수익률을 기록한 반면 임시주총에서는 음의 누적초과수익률을 기록했다. 또한 기업기준의 정기주총의 경우 주총 5 일 전부터 주총 5 일 후까지의 누적초과수익률도 $0.72 \%$ 로 유의한 수치를 기록했다. 더구나 정기주총과 임시주총의 반대의결권 행사에 따른 누적초과수익률 차이는 $\operatorname{CAR}(0,5) 1.88 \%$, $\operatorname{CAR}(0,14) 2,41 \%$ 로 정기주총이 임시주총에 비해 누적수익률이 압도적으로 높은 것으로 나타났다.

〈표 8〉 정기주총 여부에 따른 의결권 반대행사에 대한 시장반응 ***, **, *는 각각 $1 \%, 5 \%, 10 \%$ 수준에서 유의함을 의미함.

(단위: \%)

\begin{tabular}{|c|c|c|c|c|c|c|}
\hline & 표본수 & $\operatorname{CAR}(-14,0)$ & $\operatorname{CAR}(-5,5)$ & $\operatorname{CAR}(0,5)$ & $\operatorname{CAR}(0,14)$ & $\operatorname{CAR}(-14,14)$ \\
\hline \multicolumn{7}{|l|}{$\mathrm{A}$ : 전체 } \\
\hline 임시주총 & 187 & $1.20^{* *}$ & -0.47 & $-0.97^{* *}$ & $-1.57^{* *}$ & 0.35 \\
\hline 정기주총 & 635 & $-0.92^{* * *}$ & 0.27 & $0.91^{* * * *}$ & $0.84^{* * *}$ & -0.34 \\
\hline $\begin{array}{l}\text { 차이 } \\
\text { ( } \mathrm{t} \text { 값) }\end{array}$ & & $\begin{array}{c}2.11 \\
(3.62)^{* * *}\end{array}$ & $\begin{array}{r}-0.74 \\
(-1.46)\end{array}$ & $\begin{array}{c}-1.88 \\
(-3.71)^{* * *}\end{array}$ & $\begin{array}{l}-2.41 \\
(-3.35)^{* * * *}\end{array}$ & $\begin{array}{r}0.69 \\
(0.81)\end{array}$ \\
\hline \multicolumn{7}{|c|}{$\mathrm{B}$ : 기업기준 } \\
\hline 임시주총 & 60 & -0.04 & -0.99 & -0.99 & -1.22 & -1.05 \\
\hline 정기주총 & 411 & -0.39 & $0.72^{*}$ & $0.99^{* * *}$ & $1.33^{* * *}$ & 0.65 \\
\hline 차이 & & 0.35 & -1.71 & -1.98 & -2.56 & -1.70 \\
\hline (t값) & & $(0.34)$ & $(-1.92)^{* * *}$ & $(-2.33)^{* *}$ & $(-2.20)^{* *}$ & $(-1.18)$ \\
\hline
\end{tabular}

기업기준의 분석에서도 결과는 유사하게 도출되었으며 $\operatorname{CAR}(-5,5)$ 구간에서도 정기주총과 임시주총의 반대의결권 행사에 따른 누적수익률 차이가 유의하게 도출되었다. 이는 시장이 
한국증권학회지 제48권 6호 (2019)

정기주총 시 집합투자업자의 반대 의결권에 대해서는 긍정적인 신호로 해석하는 반면 임시주총 에서의 반대 의결권 행사는 부정적인 신호로 인식한다는 의미로 시사하는 바가 크다. 이는 합병이나 영업양수도와 같이 기업본질의 존재여부와 관련된 안건의 경우 대부분 임시주총에서 다루어지며 찬반 여부보다는 안건 자체의 파급효과에 따른 영향이 더 크게 나타나기 때문으로 추론할 수 있다.

\subsection{7 반대비율별}

집합투자업자는 운용하는 펀드가 다수이다. 따라서 특정기업의 특정안건에 대해 복수의 펀드를 통해 의결권을 행사할 수 있다. 집합투자업자는 특정안건에 대해 동일한 형태의 의결권을 행사하는 경우가 대부분이지만 반드시 그렇지는 않다. 보유 펀드 중 일부는 찬성의견을, 다른 일부는 반대의견을 개진할 수도 있다. 또한 일부는 찬성의견을, 다른 일부는 중립이나 행사를 하지 않을 수도 있다. 따라서 특정안건에 대해 다양한 의결권을 동시에 행사할 수 있다.

\section{〈표 9〉의결권 행사의 반대비율에 대한 시장반응}

*** ** *는 각각 $1 \%, 5 \%, 10 \%$ 수준에서 유의함을 의미함.

(단위: \%)

표본수 $\mathrm{CAR}(-14,0) \quad \mathrm{CAR}(-5,5) \quad \mathrm{CAR}(0,5) \quad \operatorname{CAR}(0,14) \quad \mathrm{CAR}(-14,14)$

\begin{tabular}{|c|c|c|c|c|c|c|}
\hline 반대 100\% & 554 & $-0.62^{*}$ & 0.11 & $0.54^{* *}$ & 0.27 & -0.45 \\
\hline 반대 50\% 100\% & 140 & 0.24 & 0.33 & 0.60 & 0.70 & 0.87 \\
\hline 반대 50\% 미만 & 128 & -0.38 & -0.07 & 0.32 & 0.24 & -0.31 \\
\hline \multicolumn{7}{|l|}{$\mathrm{B}$ : 기업기준 } \\
\hline 반대 100\% & 278 & -0.33 & $0.75^{*}$ & $1.00^{* * * *}$ & $1.30^{* *}$ & 0.60 \\
\hline 반대 50\% 100\% & 120 & -0.57 & 0.14 & 0.53 & 0.73 & 0.14 \\
\hline 반대 50\% 미만 & 73 & -0.04 & 0.22 & 0.14 & 0.44 & 0.30 \\
\hline
\end{tabular}

의결권 행사의 반대비율에 대한 시장반응은 <표 9>에 정리되어 있다. 전체 표본에서 $100 \%$ 반대 의결권만을 행사한 경우는 554 건으로 반대로 분류된 의결권의 $67.4 \%$ 를 차지했다. 반대 의결권이 $50 \%$ 이상인 경우는 140 건, $50 \%$ 이하인 경우는 각각 128 건이었다. 분석결과 $100 \%$ 반대 의결권을 행사한 경우 시장 반응은 긍정적이었다. 반대 의결권 $100 \%$ 인 경우 주총일부터 주총 5 일 후까지의 누적초과수익률은 $0.54 \%$ 였다. 반면 일부 반대 의결권 중 일부 찬성의결권을 행사한 경우에는 유의하지 않은 양의 누적초과수익률을 기록했다. 또한 반대비율이 $50 \%$ 미만인 경우에는 누적초과수익률이 더욱 하락했다.

이 같이 $100 \%$ 반대 의결권에 대한 호의적인 시장반응은 기업기준 분석 시 더욱 명확하게 도출되었다. 기업기준 시 $\operatorname{CAR}(0,5)$ 뿐 아니라 보다 장기적인 $\operatorname{CAR}(-5,5), \operatorname{CAR}(0,14)$ 에서도 양의 누적초과수익률을 기록했다. 이는 시장이 찬반 혼합형태의 의결권 행사보다 반대 $100 \%$ 의 의결권 행사를 더 선호하는 것으로 해석할 수 있다. 
Impact of Asset Management Companies' Exercise of Voting Rights on Corporate Value

\section{2 집합투자업자별 의결권 반대 행태 분석}

집합투자업자는 주식 보유 기업과의 사업관련성이나 대기업집단 소속 여부에 따라 의결권 행사에 영향을 받을 수도 있다. 기업지배구조가 취약한 국내 특수상황을 반영한다면 사업관련성 이나 대기업집단 소속 여부에 따라 특이한 형태의 결과를 도출할 수도 있는 것이다. 즉 대형 집합투자업자가 대부분 대기업집단 계열이고 보유 주식 기업과 사업관련성이 높은 현실에서 이들이 과연 제대로 의결권을 행사하고 있는가를 검증할 필요가 있다.

일단 47 개 집합투자업자 중 표본기간동안 단 1 개의 의결권을 행사한 운용사를 제외한 40 개에 대해 분석을 실시했다. 집합투자업자별 반대 의결권 행사에 대한 기간별 누적초과수익률은 <표 10>에 정리되어 있다. 분석결과 여러 기간 중 주총일부터 주총 5 일 후까지의 기간에서 가장 많은 집합투자업자들이 양의 누적초과수익률을 기록했고 이중 6 개사가 통계적으로 유의한 누적수익률을 보였다. 즉 6 개사는 의결권 반대행사를 하는 경우 평균적으로 주가가 상승함을 보인 것이다. 반면 $\mathrm{CAR}(-14,0), \mathrm{CAR}(-14,14)$ 기간에서는 절반 이상의 집합투자업자가 음의 누적초과수익률을 기록했고 이 중 각각 8개사와 4 개사가 통계적으로 유의한 음의 누적초과 수익률을 보였다. 또한 9 개사의 경우에는 5 가지 모든 기간에서 양의 초과수익률을 보였고 5 개사는 모든 기간에서 음의 초과수익률을 나타냈다.

〈표 10〉집합투자업자별 의결권 반대 행사의 대한 시장반응

+는 양의 누적초과수익률을, - 는 음의 누적초과수익률을 의미함. ++는 통계적으로 유의한 양의 누적초과수익률을, - -는 통계적으로 유의한 음의 누적초과수익률을 의미함.

(단위: \%)

\begin{tabular}{lllll}
\hline & + & - & ++ & -- \\
\hline $\operatorname{CAR}(-14,0)$ & 18 & 22 & 6 & 8 \\
$\operatorname{CAR}(-5,5)$ & 22 & 18 & 8 & 7 \\
$\operatorname{CAR}(0,5)$ & 28 & 12 & 6 & 2 \\
$\operatorname{CAR}(0,14)$ & 21 & 19 & 7 & 2 \\
$\operatorname{CAR}(-14,14)$ & 18 & 22 & 4 & 4 \\
\hline
\end{tabular}

한편 집합투자업자별로 분석 시 베어링자산운용이 130 건으로 가장 많은 반대의결권을 행사 했으며 이어 라자드코리아가 108건, 메리츠자산운용이 106건을 행사했다. 특히 베어링자산운용과 메리츠자산운용은 주총일부터 주총 14 일 후까지의 누적초과수익률이 $1.89 \%, 1.25 \%$ 로 통계적 으로 유의한 수치를 기록, 반대 의결권 행사가 많은 집합투자업자에 대한 시장반응이 긍정적임을 증명했다.

본 연구는 또한 47 개 집합투자업자를 대기업집단과 비대기업집단으로 구분하여 이들의 반대 의결권 행사에 대한 시장반응의 차이도 검증했다. 2018년 8월 현재 자산총액 5 조 원 이상의 대기업집단으로 지정된 기업은 총 60 개이며 이들의 2,083 개 계열사 중 집합투자업자는 26 개사이다. 즉 47 개 집합투자업자 중 $50 \%$ 가 넘는 26 개사가 대기업집단 계열사인 셈이다. 앞에서 언급된 100 건 이상 반대의결권을 개진한 집합투자업자 중 대기업집단은 메리츠자산운용 뿐이다. 
한국증권학회지 제48권 6호 (2019)

대기업집단 여부에 따른 의결권 반대행사 분석결과 <표 $11>$ 에서 보는 바와 같이 대기업집단의 반대의결권 행사에 대한 누적초과수익률이 비대기업집단의 누적초과수익률보다 높게 나타나 의외의 결과를 도출했다. 다만 차이는 통계적으로 유의한 수준은 아니었다. 즉 전체 표본을 대상으로 한 경우 대기업집단은 주총일부터 주총 5일 후까지 $0.67 \%$ 의 누적초과수익률을 기록한 반면 비대기업집단은 동일기간 $0.43 \%$ 의 수익률을 기록했다.

〈표 11〉대기업집단 소속 집합투자업자간 의결권 반대행사에 대한 시장반응 차이

\begin{tabular}{lcccccc}
\hline & 표본수 & $\mathrm{CAR}(-14,0)$ & $\mathrm{CAR}(-5,5)$ & $\mathrm{CAR}(0,5)$ & $\mathrm{CAR}(0,14)$ & $\mathrm{CAR}(-14,14)$ \\
\hline $\mathrm{A}$ : 전체 & & & & & \\
\hline 비대기업집단 & 520 & -0.50 & -0.22 & $0.43^{*}$ & 0.38 & -0.26 \\
대기업집단 & 302 & -0.32 & 0.70 & $0.67^{*}$ & 0.27 & -0.09 \\
\hline 차이 & -0.18 & $-0.93^{*}$ & -0.24 & 0.11 & -0.17 \\
( t값 & $(-0.31)$ & $(-1.72)$ & $(-0.58)$ & $(0.18)$ & $(-0.22)$ \\
\hline B: 기업기준 & & & & & \\
\hline 비대기업집단 & 432 & -0.39 & -0.03 & $0.47^{*}$ & 0.63 & 0.06 \\
대기업집단 & 265 & -0.40 & $0.87^{*}$ & $0.72^{* *}$ & 0.45 & 0.00 \\
\hline 차이 & 0.01 & -0.91 & -0.24 & 0.17 & 0.06 \\
(t값 & & $(-1.56)$ & $(-0.54)$ & $(0.27)$ & $(0.07)$ \\
\hline
\end{tabular}

기업기준으로 분석한 경우에도 대기업집단은 $0.72 \%$ 의 수익률을 기록, 비대기업집단의 $0.47 \%$ 보다 높은 수익률을 시현했다. 또한 기업기준의 경우 대기업집단은 $\mathrm{CAR}(-5,5)$ 기간 동안에도 $0.87 \%$ 의 양의 누적초과수익을 기록했다. 한편 대기업집단과 비대기업집단 간에는 주총 5일 전부터 주총 5일 후 기간 동안에서만 누적수익률이 통계적으로 유의한 차이를 보였다.

\section{5. 결론 및 시사점}

본 연구는 집합투자업자의 의결권 행사가 기업가치에 미치는 영향에 대해 분석을 실시했다. 2013년부터 2017년까지 50,198건의 집합투자업자 의결권과 388,486건의 개별펀드 의결권에 대한 분석결과 최근 반대의견이 증가하고 있는 것으로 밝혀졌다. 2013년 집합투자업자 기준 $1.47 \%$ 에 불과했던 반대의결권 비율은 2017 년에는 $3.29 \%$ 로 2 배 이상 증가했다. 또한 개별펀드 기준으로도 반대의결권 비율은 2017 년 $3.58 \%$ 를 기록했다. 안건별로는 이익배당이나 합병 임원임면 등에 대한 반대비율은 높은 반면 재무제표승인이나 임원보수결정에 대한 반대비율은 낮았다.

집합투자업자가 행사한 반대 의결권에 대한 집중 분석결과, 반대의결권이 행사된 기업의 주가는 주총당일 양의 초과수익률을 기록하고 주총 5일 후까지도 지속적으로 상승하는 것으로 나타났다. 반면 주총 5일 이전부터 주총일까지는 주가가 하락하는 것으로 나타났다. 주총일부터 주총 5일 후까지의 누적초과수익률은 통계적으로 유의한 양의 계수를 보였고 특히 2017년에는 큰 폭의 양의 수익률을 시현했다. 안건별로는 합병이나 임원의 임면, 합병건 반대에 대해서는 
Impact of Asset Management Companies' Exercise of Voting Rights on Corporate Value

긍정적인 시장 반응을 보였으나 이익배당에 대해서는 부정적인 시장 반응을 보였다. 동일안건에 대해 반대 펀드 수나 의결권 수에 따른 시장 반응은 일관된 패턴을 보이지 않았으나 대부분 $\cup$ 자 형태를 시현했다고 볼 수 있다. 즉 동일안건에 대한 반대 펀드 수나 의결권 수가 아주 적거나 많은 경우 시장 반응은 호의적이었다. 또한 의결권 반대비율에 따라서도 시장 반응은 상이, 반대의결권이 $100 \%$ 인 경우가 일부 찬성의결권이 혼재되어 있는 경우보다 누적초과 수익률이 월등히 높게 나타났다. 이와 함께 임시주총보다 정기주총 시 반대 의결권을 행사하는 경우 시장 반응은 훨씬 호의적인 것으로 나타났다.

의결권 행사를 집합투자업자별로 구분하여 분석한 결과 비대기업집단, 외국계 집합투자업자 들이 반대 의결권을 보다 활발히 개진하는 것으로 밝혀졌다. 또한 반대 의결권 행사가 많은 집합투자업자에 대한 시장반응이 보다 긍정적이었다. 이와 함께 비대기업집단 운용사들에 비해 대기업집단 소속의 집합투자업자들이 반대의견을 개진한 경우 통계적으로 유의하지는 않지만 행당 기업의 주가는 상승하는 것으로 나타났다.

본 연구는 최근 정치사회적 문제가 되고 있는 기관투자가의 의결권 행사를 다루었다는 점에서 의의가 있다. 기관투자가의 의결권 행사는 신의성실 원칙에 입각해 수탁자의 책임을 다한다는 원론적인 준칙을 넘어, 간접투자시장이 확대되고 있는 시점에서 투자자의 수익성 확보 차원에서도 그 중요성이 더욱 증대되고 있다. 특히 본 연구는 집합투자업자의 대기업집단 소속여부 등 기업지배구조 이슈를 다루어 공헌점이 보다 크다고 할 수 있다.

또한 최근 자료를 통해 의결권 행사와 관련된 시장반응에 대한 분석을 매우 상세히 실시했다는 점에서도 의미가 있다. 기관투자가의 의결권 행사의 중요성에 비해 관련 연구는 태부족한 상황이며 최근 자료를 활용하여 체계적으로 진행한 연구는 없는 것으로 파악된다. 본 연구는 연도별, 안건별, 펀드 수별, 반대의결권 수별, 반대비율별, 주총종류별, 집합투자업자별로 구분하여 분석, 매우 다양한 측면에서 의결권 행사와 관련된 시장반응을 분석하였다.

이와 함께 동일안건에 대한 복수의 의결권을 하나로 간주하여 분석한 점도 결과에 대한 강건성을 증대시켰다는 차원에서 공헌점이 있다. 동일안건의 복수의결권에 대해 집합투자업자 또는 기업별로 하나의 의결권으로 파악하여 분석을 실시함에 따라 통계적 오류를 검증할 수 있었다.

본 연구는 향후 기관투자가의 의결권 행사와 관련된 정책적 시사점도 제시할 수 있을 것으로 기대한다. 먼저 기관투자가의 의결권과 관련해 국민연금에만 집중되어 오던 관심을 집합투자 업자로도 이전시키는 역할을 할 수 있을 것으로 보인다. 공모펀드 237 조 원, 사모펀드 384 조 원 등 621 조 원에 달하는 자산규모13)를 보유하고 있는 펀드에 대한 의결권의 영향력을 그동안 간과해 온 면이 없지 않다. 사모펀드를 중심으로 한 간접투자 시장이 확대되고 있는 시점에 집합투자업자의 의결권 행사는 그만큼 더 중요성을 갖는 것이다. 더구나 국민연금이 국내 주식의 의결권을 위탁운용사에 이양하는 방안을 추진하고 있어 집합투자업자의 의결권 행사에 관심이 고조되고 있다.

13) 2019년 6월 말 기준. 
한국증권학회지 제48권 6호 (2019)

또한 분석결과, 동일 안건에 대해 찬반 동시행사가 아닌 반대의결권 $100 \%$ 실행 시, 정기주총 시, 특정 안건에 대한 의결권 행사 시 시장 반응이 호의적이었으므로 투자자 입장에서는 펀드 선택 시 관련 정보를 활용해 투자 수익을 확보할 수 있을 것이다. 집합투자업자 입장에서도 판매 전략의 한 수단으로 활동주의 펀드(activist fund)여부를 전면에 내세울 수 있을 것으로 보인다. 본 연구에서도 외국계 집합투자업자가 대기업집단 소속 운용사에 비해 공격적으로 반대의결권을 표명했고 시장반응도 호의적인 것으로 밝혀진 바 있다. 금융당국 입장에서도 자본시장법이나 상법, 공정거래법의 개정을 통해 기관투자가가 의결권을 제대로 행사할 수 있는 제도를 도입하거나 보완할 필요가 있을 것으로 보인다. 즉 집합투자업자의 의결권 행사 행태에 대한 분석을 통해 간접투자시장을 이용한 기업지배구조 개선방안을 모색할 수 있을 것이다. 이는 최근 제정된 스튜어드십 코드에 대해 기관투자자들이 이를 보다 적극적이고 체계적으로 도입하게 할 명분으로 이어질 수 있다.

이와 함께 집합투자업자의 의결권 공시제도에 대한 개선안의 공론화 필요성을 제기한다. 본 연구의 표본기간 중 대부분은 주총 5 일 후까지 의결권 행사 내용을 공시하게 되어 있었으나 2015년부터는 법 개정을 통해 연 1회만 공시하고 있다. 이에 따라 향후 동일한 내용에 대한 분석 시 반대의결권 행사에 대한 시장의 긍정적 반응은 도출되지 않을 수도 있다. 따라서 본 연구결과 반대의결권 행사 공시가 일종의 긍정적 정보효과로 도출된 만큼 집합투자업자의 의결권 공시제도에 대한 전반적인 재검토가 필요하다고 할 수 있다. 
Impact of Asset Management Companies' Exercise of Voting Rights on Corporate Value

\section{References}

Kwon, J., 2016, A Study for Issue of the Exercise of Voting Rights of Institutional Investors in according to the Elliotte Hedge Fund Affair: The Voting Rights of the National Pension Service and the Stewardship Code, Business Law, Vol. 26 (2), pp. 47-85.

Kim, H., and H. Im, 2018, Impact of Stewardship Code Introduction of National Pension Funds on Corporate Value, The Analysis of ESG Current Issues, Korea Corporate Governance Service.

Kim, H., and K. Yon, 2014, The Management Monitoring Effect of Institutional Investors' No Vote, Korean Journal of Financial Studies, Vol. 43 (1), pp. 1-22.

Park, Y., J. Shin, K. Wee, J. Lee, and J. Chung, 2012, Proxy Voting Policy and Strategy for National Pension Service, Korean Journal of Financial Studies, Vol. 41 (1), pp. 93-124.

Suh, E., 2009, Domestic and Overseas Status and Implications of Exercise of Voting Rights by Institutional Investors, Journal of Social Science, Vol. 26, pp. 1-37.

Ashraf, R., N. Jayaraman, and H. Ryan, 2012, Do pension-Related Business Ties Influence Mutual Fund Proxy Voting? Evidence from Shareholder Proposals on Executive Compensation, Journal of Financial and Quantitative Analysis, Vol. 47, pp. 567-588.

Brickely, J., R. Lease, and C. Smith, 1988, Ownership Structure and Voting on Antitakeover Amendments, Journal of Financial Economics, Vol. 20, pp. 267-292.

Caton, G., J. Goh, and J. Donaldson, 2001, The Effectiveness of Institutional Activism, Financial Analysts Journal, Vol. 57, pp. 21-26.

Cvijanovic, D., A. Dasgupta, and K. Zachariadis, 2016, Ties that Bind: How Business Connection Affect Mutual Fund Activism, Journal of Finance, Vol. 71, pp. 2933-2966.

Davis, G., and E. Kim, 2007, Business Ties and Proxy Voting by Mutual Funds, Journal of Financial Economics, Vol. 85, pp. 552-570.

Matvos, G., and M. Ostrovsky, 2010, Heterogeneity and Peer Effects in Mutual Fund Proxy Voting, Journal of Financial Economics, Vol. 98, pp. 90-112.

Morgan, A., A. Poulsen, J. Wolf, and T. Yang, 2011, Mutual Funds as Monitors: Evidence from Mutual Fund Voting, Journal of Corporate Finance, Vol. 17, pp. 914-928.

Nesbitt, S., 1994, Long-Term Rewards from Shareholder Activism: A Study of the CalPERS Effect, Journal of Applied Corporate Finance, Vol. 6, pp. 75-80.

Opler, T. C., and J. Sokobin, 2000, Does Coordinated Institutional Activism Work? An Analysis of the Activities of the Council of Institutional Investors, Working Paper, Ohio State University.

Ng, L., Q. Wing, and N. Zaiats, 2009, Firm Performance and Mutual Fund Voting, Journal of Banking and Finance, Vol. 33, pp. 2207-2217.

Rothberg, B., and S. Lilien, 2006, Mutual Funds and Proxy Voting: New Evidence on Corporate Governance, Journal of Business Technology Law, Vol. 1, pp. 157-184. 